\title{
POTENSI EKSTRAK DAUN JAMBU BIJI (PSIDII FOLIUM) SEBAGAI \\ BAHAN ALTERATIF TERHADAP KADAR HEMOGLOBIN PADA REMAJA PUTERI DI SMK BHAKTI NUSANTARA
}

\author{
${ }^{1}$ Angela Ditauli Lubis \\ ${ }^{1}$ Stikes Borneo Cendekia Medika Pangkalan Bun \\ Email : angela.lubis03@gmail.com
}

\begin{abstract}
Abstrak
Latar Belakang : Anemia merupakan salah satu masalah kesehatan di seluruh dunia, terutama dinegara berkembang. Angka kejadian anemia pada remaja puteri sebesar $57,1 \%$. Penatalaksanaan anemia yang dilakukan dengan pemberian tablet $\mathrm{Fe}$, tetapi tablet $\mathrm{Fe}$ memiliki efek samping yaitu susah BAB dan rasa mual sehingga menyebabkan kepatuhan konsumsi obat berkurang. Salah satu alternatif pencegahan anemia adalah dengan menggunakan ekstrak daun jambu biji yang dapat menurunkan efek samping rasa mual dan mengandung antioksidan baik bagi tubuh dan kadar profil darah.
\end{abstract}

Tujuan Penelitian : Membuktikan pengaruh pemberian ekstrak daun jambu biji terhadap perubahan kadar hemoglobin pada remaja puteri.

Metode Penelitian : Jenis metode penelitian ini yang digunakan adalah True Eksperiment. Rancangan penelitian yang digunakan adalah pretest dan post test control group design. Dengan jumlah sampel 30 remaja puteri terbagi dalam 2 kelompok yaitu kelompok kontrol yang diberikan Fe $60 \mathrm{mg}$ dan kelompok intervensi yang diberikan Fe $60 \mathrm{mg}$ dan ekstrak daun jambu biji $500 \mathrm{mg}$. Analisis data menggunakan Wilcoxon dan Independent T-Test

Hasil Penelitian : : Setelah diberikan intervensi dengan mengkonsumsi ekstrak daun jambu biji selama 14 hari terdapat perbedaan nilai Hemoglobin setelah diberikan perlakuan pada kedua kelompok. Rerata mean Hemoglobin kelompok perlakuan > Kelompok kontrol $(11.47 \mathrm{ng} / \mathrm{dl}>11.11 \mathrm{ng} / \mathrm{dl})$,

Simpulan : Ekstrak daun jambu biji berpengaruh terhadap peningkatan kadar Hemoglobin

Saran. Ekstrak daun jambu biji dapat dijadikan alternatif terapi peningkatan Hemoglobin

Kata Kunci : Ekstrak daun jambu biji, Hemoglobin,

\section{POTENTIAL OF SEED LEAVES (PSIDII FOLIUM) EXTRACTS AS ALTERNATIVE MATERIALS IN HEMOGLOBIN LEVELS IN YOUTH TEENAGE (CASE STUDY IN BHAKTI NUSANTARA VOCATIONAL SCHOOL)}

\author{
Angela Ditauli Lubis ${ }^{1}$ \\ ${ }^{1}$ Stikes Borneo Cendekia Medika Pangkalan Bun
}


Email : angela.lubis03@gmail.com

\begin{abstract}
Background: Anemia is a health problem throughout the world, especially in developing countries. The incidence of anemia in adolescent girls is $57.1 \%$. Management of anemia was carried out by administering Fe tablets, but Fe tablets had side effects, namely defecation and nausea, which led to reduced compliance with drug consumption. One alternative to preventing anemia is to use guava leaf extract which can reduce nausea side effects and contain antioxidants for the body and blood profile levels.

Objective : To prove the influence of guava leaf extract on changes in hemoglobin levels

Methods : The type of research method used is True Experiment. The research design used was pretest and post-test control group design. With a sample of 30 female adolescents divided into 2 groups, namely the control group given Fe 60 $\mathrm{mg}$ and the intervention group gave Fe $60 \mathrm{mg}$ and guava leaf extract $500 \mathrm{mg}$. Data analysis using Wilcoxon and Independent T-Test.

Results : After being given an intervention by consuming guava leaf extract for 14 days there were differences in Hemoglobin values after being given treatment in both groups. Mean mean Hemoglobin treatment group> Control group (11.47 $\mathrm{ng} / \mathrm{dl}>11.11 \mathrm{ng} / \mathrm{dl}$ ),

Conclusion : Guava leaf extract has an effect on increasing hemoglobin levels

Suggestion. Guava leaf extract can be used as an alternative therapy for increased hemoglobin
\end{abstract}

Keywords : Guajava Leaf Exctract, Hemoglobin,

\section{Latar Belakang}

Anemia merupakan salah satu masalah kesehatan di seluruh dunia terutama negara berkembang yang diperkirakan $30 \%$ penduduk dunia menderita anemia ${ }^{1}$. Anemia banyak terjadi pada masyarakat terutama pada remaja dan ibu hamil. Anemia pada remaja putri sampai saat ini masih cukup tinggi ${ }^{1}$.

Menurut data hasil Riskesdas prevalensi anemia di Indonesia yaitu $21,7 \%$, dengan penderita anemia berumur 5-14 tahun sebesar 26,4\% dan $18,4 \%$ penderita berumur $15-24$ tahun 2. Data Survei Kesehatan
Rumah Tangga (SKRT) tahun 2012 menyatakan bahwa prevalensi anemia pada remaja putri usia $10-18$ tahun 2012 sebesar $57,1 \%$ dan usia 19-45 tahun sebesar $39,5 \%{ }^{3}$. Wanita mempunyai resiko terkena anemia paling tinggi terutama pada remaja putri ${ }^{4}$.

Terdapat banyak jenis anemia, namun yang paling banyak terjadi adalah anemia defisiensi besi, yaitu anemia diakibatkan kekurangan zat besi yang merupakan bahan utama pembentukan hemoglobin, sehingga terjadi gangguan sintesis 
hemoglobin yang pada akhirnya menyebabkan penurunan transport oksigen dalam darah 5. Anemia defisiensi besi dianggap menjadi faktor yang paling penting dalam peningkatan beban penyakit di seluruh dunia, umumnya terjadi pada masa anak-anak dan wanita hamil ${ }^{6}$.

Remaja putri mempunyai risiko yang lebih tinggi terkena anemia daripada remaja putra. Pertama karena setiap bulan pada remaja putri mengalami haid. Seorang wanita yang mengalami haid yang banyak selama lebih dari lima hari dikhawatirkan akan kehilangan besi, sehingga membutuhkan besi pengganti lebih banyak daripada wanita yang haidnya hanya tiga hari dan sedikit. Kedua adalah karena remaja putri seringkali menjaga penampilan, keinginan untuk tetap langsing atau kurus sehingga berdiet

Di dalam tubuh manusia, jumlah zat besi sangat bervariasi tergantung pada umur, jenis kelamin, dan kondisi fisiologis tubuh ${ }^{8}$. Pada orang dewasa sehat, jumlah zat besi diperkirakan lebih dari $4000 \mathrm{mg}$ dengan sekitar $2500 \mathrm{mg}$ ada dalam hemoglobin ${ }^{8}$. Sebagian zat besi dalam tubuh (sekitar $1000 \mathrm{mg}$ ) disimpan di dalam hati dengan bentuk ferritin. Pada saat konsumsi zat besi dari makanan tidak cukup, zat besi ferritin dikeluarkan untuk memproduksi hemoglobin ${ }^{8}$. Pada saat tubuh tidak memproduksi zat besi dari makanan karena konsumsi kandungan makanan yang dan mengurangi makan. Diet yang tidak seimbang dengan kebutuhan zat gizi tubuh akan menyebabkan tubuh kekurangan zat gizi yang penting seperti besi ${ }^{7}$.

Secara umum ada beberapa faktor penyebab anemia yaitu kehilangan darah secara kronis atau banyak darah menstruasi, lama menstruasi, asupan zat besi tidak cukup, penyerapan yang tidak adekuat dan peningkatan kebutuhan akan zat besi, status gizi, penyakit malaria, infeksi-infeksi lain, serta pengetahuan tentang anemia ${ }^{7}$.Faktor lama menstruasi dan status gizi adalah faktor yang sangat berhubungan dengan anemia. Secara normal, setiap harinya seorang wanita akan kehilangan sekitar 1-2 mg zat besi melalui ekskresi secara normal $^{7}$.

mengandung zat besi kurang, cadangan zat besi dari ferritin digunakan terus menerus, sehingga cadangan zat besi tersebut habis, hal tersebut yang bisa menyebabkan terjadinya anemia ${ }^{8}$. Kurang zat gizi mikro dan makro menyebabkan tubuh menjadi kurus dan berat badan turun drastis, pendek, anemia, sakit terus - menerus, sehingga sebagai calon ibu tidak sehat ${ }^{8}$.

Menurut Prawirohardjo menyatakan bahwa pencegahan anemia yaitu setiap remaja diberi sulfas ferrosus glukonas ferrosus cukup 1 tablet sehari. Remaja dianjurkan untuk makan lebih 
banyak protein dan sayur-sayuran yang mengandung banyak mineral serta vitamin. Kadang - kadang tablet tambah darah menimbulkan perasaan tidak enak seperti sakit perut, tidak enak, mual, susah buang air besar, tinja berwarna hitam, ini karena kandungan zat besinya tinggi yaitu $200 \mathrm{mg}$ atau $60 \mathrm{mg}$ elemental dan $0,25 \mathrm{mg}$ asam folat, hal ini menyebabkan orang cenderung tidak patuh mengkonsumsi tablet besi ${ }^{8}$.

Sebagai salah satu alternatif yang dapat digunakan untuk meningkatkan kadar profil darah adalah dengan memanfaatkan daun jambu (Psidii folium). Daun jambu biji mudah didapatkan karena dapat tumbuh diberbagai daerah di Indonesia. Daun jambu lebih mudah didapatkan dibandingkan dengan buah jambu biji, hal tersebut Sel endotel pembuluh darah adalah lapisan sel gepeng yang melapisi permukaan dalam pembuluh darah, dan berhubungan langsung dengan darah dan produk darah lainnya yang mengalir didalamnya.

Antioksidan pada flavonoid dapat menyumbangkan atom hidrogennya. Flavonoid akan teroksidasi dan berikatan dengan radikal bebas, sehingga radikal bebas menjadi senyawa yang lebih stabil ${ }^{12}$. Analisis fitokimia oleh Arya tahun 2012 menyatakan bahwa ekstrak daun jambu biji memiliki aktivitas senyawa antioksidan salah satunya adalah senyawa golongan flavonoid, karena kemampuannya mereduksi dikarenakan daunnya lebih mudah dicari tanpa harus menunggu bunganya berbuah. Daun jambu biji mengandung minyak atsiri, senyawa tanin, saponin, terpenoid, flavonoid, antosianin dan alkaloid ${ }^{9}$. Menurut beberapa penelitian dalam jurnal FMIPA UI tahun 2011, daun jambu biji telah terbukti memiliki berbagai efek farmakologis, antara lain analgesik, antiinflamasi, antivirus dan antitumor, antidiare, antibatuk, anti bakteri, antiplak gigi, antidiabetes, antihipertensi, hepatoprotektif, dan antioksidan ${ }^{11}$.

Kandungan flavonoid dalam ekstrak daun jambu memiliki aktivitas antioksidan yang bekerja sebagai penangkap radikal bebas tentu dapat digunakan untuk memperbaiki atau mengembalikan fungsi endotelia pembuluh darah ${ }^{10}$. radikal bebas atau kemampuan menurunkan bilangan oksidasi dalam darah.

Berdasarkan uraian diatas, membuat peneliti tertarik untuk melakukan penelitian tentang pengaruh pemberian ekstrak daun jambu biji (Psidii Folidum) terhadap perubahan kadar profil darah pada remaja putri di SMK Bahkti Nusantara

\section{Tujuan penelitian}

Membuktikan pengaruh pemberian ekstrak daun jambu biji terhadap perubahan kadar Hemoglobin pada remaja puteri di SMK Bhakti Nusantara 


\section{Metode Penelitian}

Penelitian ini merupakan penelitian True experiment dengan rancangan pretest dan posttest control group design. Jumlah Sampel 30 terbagi dalam 2 kelompok yiatu 15 sampel kelompok kontrol dan 15 sampel kelompok perlakuan. Kriteria inklusi remaja puteri berusia 15-18 tahun, Kadar hemoglobin awal 10-11,9 $\mathrm{gr} / \mathrm{dl}$. Variabel yang diteliti yaitu kadar Hemoglobin darah sebelum dan setelah diberikan perlakuan. Dilakukan pemberian ekstrak daun jambu biji selama 14 hari. Alat ukur yang digunakan kuesioner, pengukur $\mathrm{Hb}$ Digital. Analisa Data dilakukan yaitu Analisa Univariat, dilakukan untuk menganalisa secara deskriptif variabel penelitian dengan menguji normalitas data. Analisis deskriptif dilakukan untuk menggambarkan setiap variabel yang diteliti secara terpisah dengan cara membuat tabel mean. Median, standar deviassi dari massing-massing variabel. Analisa Bivariat, dilakukan untuk menguji masing-masing variabel antara dua kelompok kontrol dan kelompok intervensi, dalam data penelitian ini data tidak berdistribusi normal, maka uji yang digunakan jenis non parametrik dengan uji yang digunakan adalah mann whitney test pada variabel, sedangkan pada variabel tidak berpasangan menggunakan uji wilcoxon test.

\section{Hasil Penelitian}

Analisis Univariat Karakteristik Responden

Tabel 4.1 Karekteristik responden pada kelompok intervensi dan kontrol

\begin{tabular}{cccc}
\hline Variabel & \multicolumn{2}{c}{ Kelompok } & \\
\cline { 2 - 4 } & Intervensi & Kontrol & p-value \\
& Mean \pm SD & Mean \pm SD & \\
\hline Usia & $16.40 \pm 0.736$ & $15.86 \pm 0.639$ & 0.310 \\
IMT & $20.33 \pm 1.447$ & $20.40 \pm 2.557$ & 0.478 \\
\hline
\end{tabular}

Berdasarkan tabel 4.1 dapat disimpulkan bahwa rata-rata umur responden penelitian berada pada usia 16 tahun pada kelompok intervensi dan 15 tahun untuk kelompok kontrol dengan nilai $\mathrm{p}$ - value >0,05. Data IMT untuk kelompok intervensi dan kontrol yaitu 20 dengan nilai $\mathrm{p}$ value $>0,05$ yang artinya bahwa untuk Usia dan IMT tidak dapat perbedaan.

Gambaran Kadar Hemoglobin (Hb)

Tabel 4.2 Gambaran Kadar Hemoglobin

\begin{tabular}{cccc}
\hline Variabel & Sebelum & Sesudah & P value \\
\cline { 2 - 3 } Hemoglobin & Mean \pm SD & Mean \pm SD & \\
\hline Intervensi & $10.77 \pm 0.454$ & $11.47 \pm 0.589$ & $0.001^{*}$ \\
Kontrol & $10.68 \pm 0,383$ & $11,11 \pm 0.511$ & $0.000^{* *}$ \\
\hline & Intervensi & Kontrol \\
\hline
\end{tabular}




\begin{tabular}{|c|c|}
\hline $\begin{array}{cc}\Delta & 0.70 \pm 0.342 \\
\end{array}$ & $0.42 \pm 0.296 \quad 0.027 * * *$ \\
\hline \multirow{3}{*}{\multicolumn{2}{|c|}{$\begin{array}{l}* \text { Wicoxon ** Paired sampel T-Test } * * * \text { Independent sampel T-Test } \\
\text { Pada tabel } 4.2 \text { menunjukan } \\
\text { bahwa hasil uji statistik dengan } \\
\text { bermakna kadar hemoglobin sebelum }\end{array}$}} \\
\hline & \\
\hline & \\
\hline menggunakan uji Wilcoxon & dan sesudah perlakuan pada \\
\hline menunjukan, rerata hemoglobin & kelompok kontrol. \\
\hline sebelum dan sesudah pada kelompok & Hasil uji beda pada kelompok \\
\hline intervensi didapatkan niai $\mathrm{p}$ va & tidak berpasa \\
\hline 0,05, maka dapat disimpulkan bahwa & kadar hemoglobin menunjuka \\
\hline & \\
\hline dengan hari keempat belas sudah ada & Independent Sampel T-Test dimana $\mathrm{p}$ \\
\hline perbedaan antara kadar hemoglobin & value $<0,05$ sehingga dapat \\
\hline sebelum dan sesudah diberika & disimpulkan bahwa ada perbe \\
\hline perlakuan. $\quad$ Sedangkan & kadar Hemoglobin antara kelompok \\
\hline kelompok kontrol dilakukan uji & intervensi dan kelompok kontrol \\
\hline Paired Sampel T-Test didapatkan & diberikan \\
\hline
\end{tabular}
nilai $\mathrm{p}$ value $<0,05$, maka dapat

\section{PEMBAHASAN}

\section{Pengaruh ekstrak daun jambu biji Terhadap Kadar Hemoglobin}

Untuk melihat perbedaan kadar hemolgobin antara kelompok intervensi yang mengkonsumsi ektrak daun jambu biji dengan kelompok kontrol yang mengkonsumsi tablet $\mathrm{Fe}$, dilakukan pengukuran dengan menggunakan uji Independen t-test Berdasarkan hasil uji Independen $t$-test didapatkan nilai $p$-value < $\alpha(0,05)$, maka dapat disimpulkan bahwa pemberian ekstrak daun jambu biji dengan dosis 500mg selama 14 hari pada remaja puteri ternyata berpengaruh secara bermakna terhadap perubahan kadar hemoglobin sebelum diberikan sumsum tulang dan memiliki efek immunostimulan ${ }^{15}$.

Antioksidan adalah senyawa yang melawan fek radikal bebas dan mencegah atau menunda oksidasi perlakuan dan setelah diberikan perlakuan.

Ekstrak daun jambu biji mengandung senyawa flavonoid, Senyawa flavonoid merupakan senyawa polifenol yang berperan sebagai antioksidan, yang didalam sel darah dapat bertindak sebagai penampung radikal hidroksil dan superoksida sehingga melindungi lipid membran dan mencegah kerusakan sel. Senyawa flavonoid hasil ekstrak daun jambu biji dapat meningkatkan proses eritropoesis (pembentukan eritrosit) dalam

yang tidak diinginkan atau kerusakan DNA, protein dan lemak ${ }^{16}$. Antioksidan dapat menunda atau menghambat reaksi oksidasi yang ditimbulkan oleh radikal bebas dan 
menghancurkan atau menetralkan radikal bebas yang dapat menyebabkan kerusakan sel dan molekul-molekul penting dalam tubuh seperti DNA, protein dan lemak. Antioksidan hanya dapat bertahan beberapa jam didalam tubuh karena dapat larut dalam lemak atau air. Oleh karena itu antioksidan sangat diperlukan bagi tubuh ${ }^{17}$.

Adanya asupan senyawa antioksidan dari ekstrak daun jambu biji maka serangan radikal bebas terhadap sel darah dapat diminimalisir dan proses pembentukan sel darah dapat meningkat, sehingga kadar hemoglobin dapat dipertahankan. Selain itu hasil penelitian unigwe dan Nwakpu menunjukkan bahwa bahan aktif flavonoid dapat meningkatkan kadar hemoglobin ${ }^{18}$.

Vitamin C diperlukan untuk meningkatkan penyerapan zat besi di dalam tubuh. Penambahan vitamin $\mathrm{C}$ dan $\mathrm{Fe}$ dapat meningkatkan kadar $\mathrm{Hb}$ pada remaja putri. Vitamin $\mathrm{C}$ mempunyai fungsi dalam metabolisme $\mathrm{Fe}$ terutama untuk mempercepat proses penyerapan $\mathrm{Fe}$ dalam usus dan proses pemindahannya ke dalam darah. Vitamin $\mathrm{C}$ juga terlibat dalam mobilisasi simpanan $\mathrm{Fe}$ terutama dalam pembentukan hemosiderin dalam limpa. 19

4. Kementerian Kesehatan RI. Profil Kesehatan Indonesia 2012. Kementerian Kesehatan RI. 2013.

\section{Kesimpulan}

Bahwa pemberian kapsul ekstrak daun jambu biji pada remaja puteri di SMK Bahkti Nusantara dapat meningkatkan kadar hemoglobin dan kadar Ferritin secara signifikan. Kapsul ekstrak daun jambu biji dapat dikonsumsi oleh remaja puteri untuk mencegah terjadinya anemia, bagi tenaga kesehatan khususnya bidan dapat menggunakan kapsul ekstrak daun jambu sebagai alternatif pencegahan anemia pada remaja puteri. Bagi peneliti selanjutnya diharapkan dapat dijadikan sebagai bahan refrensi dan perlu dilakukan penelitian lebih lanjut mengenai pembuatan ekstrak daun jambu biji dengan penambahan aroma rasa tanpa mengurangi kandungan dari ekstrak daun jambu biji tersebut

\section{DAFTAR PUSTAKA}

1. World Health Organization. Worldwide Prevalency Of Anemia WHO Global database on Anemia. Geneva WHO Press. 2013.

2. Kementerian Kesehatan RI. Laporan Hasil Riset Kesehatan Dasar (Riskesdas). Kementerian Kesehatan RI. 2013.

3. Departemen Kesehatan RI. Survey Kesehatan Rumah Tangga. Jakarta. 2013.

5. Price. A. Sylvia. Wilson. M. Patofisiologi Konsep Klinis Proses Penyakit. Jakarta, EGC. 2005. 
6. World Health Organization. Worldwide Prevalence Of Anemia. WHO. 2008.

7. Arisman. Gizi Dalam Daur Kehidupan. Jakarta, EGC. 2004.

8. Prawirohardjo, Sarwono. Ilmu Kandungan. Jakarta, PT. Bina Pustaka Sarwono Prawirohardjo. 2009.

9. Begum. S, Hasan SI, Siddiqui BS. Two New Triterpenoids From The Fresh Leaves of Psidium Guajava. Planta Med. 2010;62(12);114952.

10. Li J, Chen F, Luo J. GC-MS Analysis Of Essential Oil From The Leaves Of Psidium Guajava. Zhong Yao Cai. 2009 ;22(2);7880.

11. Rochmasari, Yuniar. Studi Isolasi dan Penentuan Standar Molekul Senyawa Kimia Dalam Fraksi Netral Daun Jambu Biji Australia (Skripsi). FMIPA UI. 2011.

12. Egharevba, $\mathrm{H} \quad \mathrm{O}$ et.al. Standarization Of Herbal Medicines - A review. International Journal Of Biodiversity and Converzation. 2010;4(3);101-112.

13. Gutierrez, P.M.P,. Mitchel, S., and Solis, R.V. Psidium Guajava : a review of its traditional uses, phytochemistry and pharmacology, J. Etnopharmaco. 2008;117(1);1-27.

14. Kementerian Kesehatan Republik Indonesia. Pedoman Interpretasi Data Klinik. Jakarta. 2011.

15. Miryanti Arry. Ekstraksi Antioksidan Dari Kulit Buah Manggis (Garcinia Mangostana L). Bandung. 2011.

16. Endang Palupi. Degradasi Mrthilene Blue Dengan Metode Fotokatalis dan Fotoelektrokatalis
Menggunakan Film $\mathrm{TiO}_{2}$. Bogor, Departemen Fisika IPB. 2009.

17. Plank, N. Real Food : Hidup Bebas Penyakit dengan Makanan Alami. Bloomsburry Publishing, New York dan London. 2007.

18. Chika Unigwe dan Nwapku. The Effect of Garcinia Kola Seed Containing Active Ingredients Flavonoids Can Be Increase Hemoglobin $(\mathrm{Hb})$, Erythrocyte and Hematocrit Term Rabbbit. University Of York. 2009.

19. Sagung M.D. Pengaruh Pemberian Sirup Besi, Vitamin C Dan Vitamin A Terhadap Kadar $\mathrm{Hb}$ Balita Dengan Anemia (Penelitian Eksperimental Di Kabupaten Buleleng). In Surabaya: Departemen Gizi Kesehatan FKM Unair (2008).

20. Gropper SS. Advance Nutrition And Human Metabolism. In Amerika Serikat: Wadsworth, Cengage Learning Ed 5, (2009).

21. Sumanthi K. Role Of Serum Ferritin In Critically III Patients. In Int J Pharm Bio Sci 404-406 (2013).

22. Kell DB. Serum Ferritin Is An Important Inflammatory Disease Marker, As It Is Mainly A Leakage Product From Damaged Cells. In Metallomics 748-751 (2013) 